\title{
Genetic and otolith isotopic markers identify salmon populations in the Columbia River at broad and fine geographic scales
}

\author{
Rachel Barnett-Johnson • David J Teel • \\ Edmundo Casillas
}

Received: 30 September 2009 / Accepted: 12 May 2010 /Published online: 16 June 2010

(C) The Author(s) 2010. This article is published with open access at Springerlink.com

\begin{abstract}
Processes occurring in freshwater, estuarine, and marine habitats strongly influence the growth, survival and reproductive success of salmonids. Nonetheless, implementing an ecosystem model explicitly linking these important habitats has been hindered by the inability to track the source identity of individuals where they co-occur. Here we explore the development and integration of natural markers- molecular and isotopic to characterize the natal sources of Chinook salmon (Oncorhynchus tshawytscha) in the Mid and Upper Columbia River summer/fall-run (UCR Su/F) population. Microsatellite DNA markers identified the majority of juveniles collected in rivers and hatcheries
\end{abstract}

R. Barnett-Johnson $(\bowtie)$

Institute of Marine Sciences,

University of California Santa Cruz,

Santa Cruz, CA, USA

e-mail: Barnett-Johnson@biology.ucsc.edu

D. J. Teel

Northwest Fisheries Science Center,

NOAA Fisheries Service,

Manchester, WA, USA

E. Casillas

Northwest Fisheries Science Center,

NOAA Fisheries Service,

East Seattle, WA, USA

Present Address:

R. Barnett-Johnson

Division of Environmental Affairs,

US Bureau of Reclamation,

Sacramento, CA, USA in the Mid and Upper Columbia River watershed to the Summer/Fall-run population in this watershed with $90 \%$ posterior probabilities of group membership. Strontium isotopes $\left({ }^{87} \mathrm{Sr} /{ }^{86} \mathrm{Sr}\right)$ measured in the natal rearing portion of the otolith showed significant geographic variation among natal rivers and hatcheries. Natal sites exhibited a wide dynamic range in ${ }^{87} \mathrm{Sr} /{ }^{86} \mathrm{Sr}$ source signatures (0.7043-0.7142), such that on average $61 \%$ of individuals were correctly classified to the location from which they were collected. We found that multilocus genotypes and otolith ${ }^{87} \mathrm{Sr} /{ }^{86} \mathrm{Sr}$ ratios collected on the same individuals were complementary markers when applied in a hierarchy. Microsatellites successfully assigned individuals to the broader UCR Su/F genetic group and ${ }^{87} \mathrm{Sr} /{ }^{86} \mathrm{Sr}$ provided finer-scale geographic assignments to five natal river and hatchery groups nested within the UCR $\mathrm{Su} / \mathrm{F}$ population. The temporal stability of both genetic and ${ }^{87} \mathrm{Sr} /{ }^{86} \mathrm{Sr}$ markers, together with the coast-wide microsatellite baseline currently being used for mixedstock fisheries management supports the further development and integration of ${ }^{87} \mathrm{Sr} /{ }^{86} \mathrm{Sr}$ markers to potentially achieve finer levels of stock resolution. Stock identification at the scales of individual rivers and hatcheries would help elucidate the abundance, distribution, and the relative contributions of natal sources important for the recovery and spatial management of Chinook salmon.

Keywords Conservation - Ecology · Freshwater . Habitat $\cdot$ Management $\cdot$ Marine 


\section{Introduction}

A successful life history depends on an organism's ability to find suitable habitat in all phases of their life cycle. This can be particularly challenging for the many fish species that rely on different habitats between juvenile and adult stages that are spatially distant from one another. Thus, one of the outstanding issues in fisheries ecology is identifying habitats critical to the growth, survival and reproductive success of species that are endangered and targeted by fisheries. Yet, there are relatively few methods to estimate movement patterns of migratory fish and their habitat linkages among freshwater, estuarine and marine environments.

Many fisheries applications would benefit from identifying connectivity of populations over short and long temporal scales as well as across broad geographic (e.g., species' distribution) and local spatial scales (Cadrin et al. 2005; Botsford et al. 2009; Cowen and Sponaugle 2009). Several biogeography studies in marine fishes have found no genetic differentiation across species' distributions, although only a few migrants per generation could account for this lack of genetic structure (Palumbi 2004; reviewed in Selkoe et al. 2008). Similarly, recent studies using otolith microchemistry have found significant variation of elements at surprisingly small spatial (10 s of $\mathrm{km}$ ) and temporal scales, limiting its utility for many marine applications (Gillanders 2002; Ruttenberg and Warner 2006; Miller 2007; Standish et al. 2008). There is a growing appreciation that genetic and otolith elemental signatures generally test for connectivity among populations at different scales (Thresher 1999; Barnett-Johnson 2007; Selkoe et al. 2008).

Accurate homing behavior in space and time for salmonids results in reproductively isolated populations and allows adaptive divergence to occur among populations in the freshwater (e.g., reviewed in Taylor 1991). Indeed, salmon populations have diverged in a number of traits due to spatially varying selection pressures (e.g., Carlson and Quinn 2007; Carlson et al. 2009) combined with the fact that many traits are heritable (reviewed in Carlson and Seamons 2008). Information for several traits that differ among Chinook salmon (Oncorhynchus tshawytscha) populations has been synthesized with genetic and environmental data to identify broad conservation units in the United States that generally correspond geograph- ically to regional watersheds (Evolutionarily Significant Units (ESUs); Myers et al. 1998). The genetic divergence among freshwater salmon populations results in genetic markers that can be used to track the abundance and distribution of salmon populations during their non-reproductive life history stage in estuarine and marine systems (Utter et al. 1987; Seeb et al. 2007).

Microsatellites have been the genetic marker of choice in ecological and conservation genetics studies in the last decade due to their high variability and power to resolve population structure and to assign individual fish to populations or parents (O'Connell and Wright 1997; Hansen et al. 2001; Planes et al. 2009). For Pacific salmon, efforts to standardize genetic data among labs have permitted the development of geographically broad datasets (Moran et al. 2006) including a coast wide microsatellite baseline for Chinook salmon stock identification (Seeb et al. 2007). More recently, differentiation among Chinook salmon populations has also been examined using single nucleotide polymorphisms (SNPs; Narum et al. 2008). However, these genetic approaches are only effective for differentiating among genetically distinct groups of fish and many spawning populations of Chinook salmon are connected by recent or ongoing interbreeding. While populations in proximate rivers are often linked by natural exchanges of spawners, many populations are currently connected due to alterations in migration and spawning habitats and by transfers of hatchery broodstocks across watersheds. Therefore, the need remains to identify the specific natal river or hatchery of origin of fish in population mixtures to meet conservation and management goals.

The Columbia River was historically among the most productive rivers for anadromous salmonids in the world (Chapman 1986). Summer and fall run (time of adult return to freshwater) Chinook salmon populations in the upper river are major contributors to the commercial and recreational fishery off the coasts of Washington, British Columbia, and southeast Alaska (Utter et al. 1987; Weitkamp 2010). These populations comprise the Upper Columbia Summer and Fall Run ESU (UCR Su/F; Myers et al. 1998) and are genetically distinct from Mid and Upper Columbia River spring-run populations and from other summer and fall-run groups in Columbia River watersheds (Utter et al. 1995; Waples et al. 2004). However, overall genetic differentiation among natal 
rivers within the UCR $\mathrm{Su} / \mathrm{F}$ ESU is small, likely a result of blockage of spawning habitat upstream of Grand Coulee Dam and subsequent fishery and hatchery management actions (Utter et al. 1995). In addition, several current hatcheries in different rivers rear and release fish derived from common UCR Su/F stocks, making fine-scale genetic identification of individuals very difficult. Otolith-based techniques have provided finer scale identification of sources in high gene flow systems where environmental heterogeneity exists (Secor 1999; Campana and Thorrold 2001; Gillanders 2002).

Strontium isotope $\left({ }^{87} \mathrm{Sr} /{ }^{86} \mathrm{Sr}\right)$ ratios in otoliths and rivers largely reflect the age and mineralogy of the surrounding surficial geology (Kennedy et al. 1997; Barnett-Johnson et al. 2008). Since Sr isotopes, like other trace elements, are permanently incorporated in the otolith's carbonate matrix, ${ }^{87} \mathrm{Sr} /{ }^{86} \mathrm{Sr}$ can be measured from discrete daily growth increments deposited throughout the life of a fish (Kennedy et al. 1997, Ingram and Weber 1999, Barnett-Johnson et al. 2005). Barnett-Johnson et al. (2008) found significant variation in natal otolith
${ }^{87} \mathrm{Sr} /{ }^{86} \mathrm{Sr}$ values among the major salmon rivers and hatcheries in the California Central Valley, which permitted Chinook salmon to be linked to their natal sources within the fall-run ESU with high classification accuracy (98\%). Rivers providing salmon rearing habitat in the Columbia River watershed system drain areas of contrasting lithologies, thus showing similar promise for the development of $\mathrm{Sr}$ isotopic markers within the watershed (Fig. 1).

Integrating intrinsic markers is a powerful approach to tracking fish movement at different scales, as no single marker has yet achieved this goal (Wood et al. 1989; Hobson et al. 2009; Planes et al. 2009). Molecular techniques can detect restricted gene flow and the resultant genetic divergence among groups over evolutionary time scales, whereas some chemical signatures in otoliths reflect only those environmental differences experienced by individuals in their lifetime (i.e., ecological time scales). To date, only work by Milton and Chenery (2001) on a Tropical Shad (Tenualosa ilisha), Miller et al. (2005) on Black Rockfish (Sebastes melanops), Barnett-Johnson (2007) on

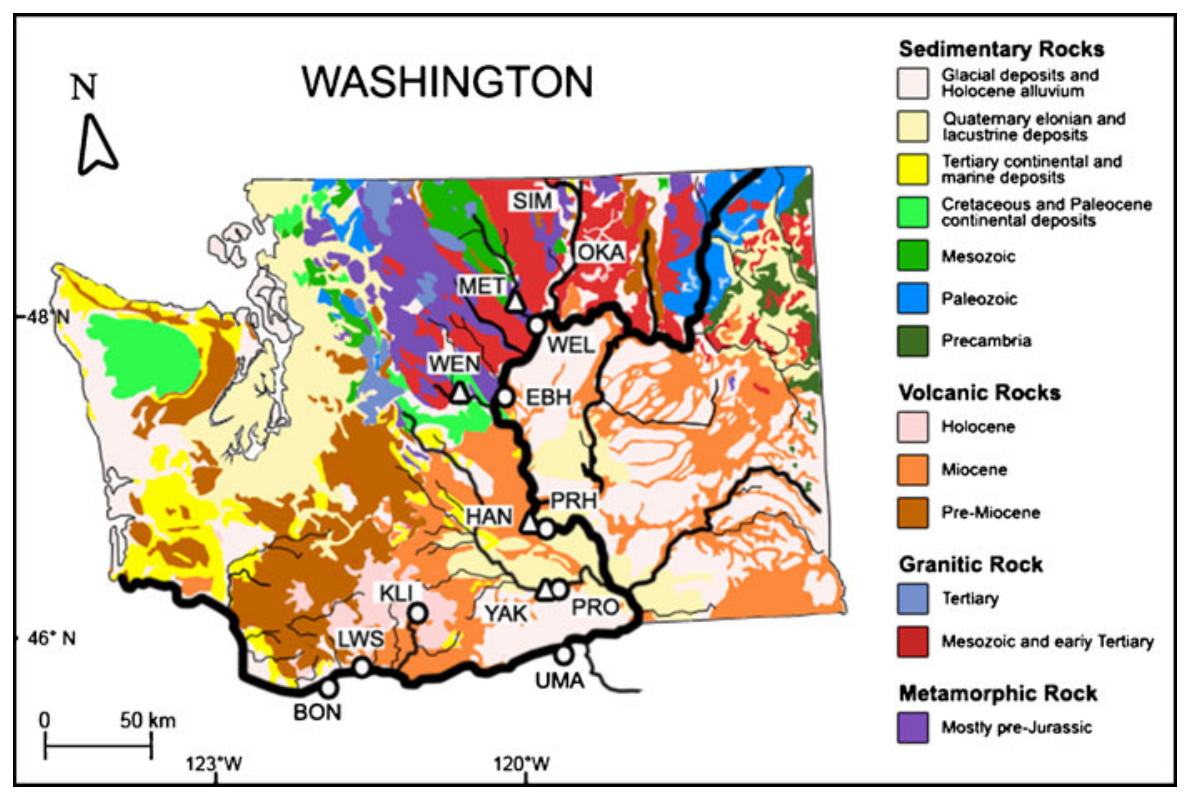

Fig. 1 Map of geology, and major salmon rivers (open triangles) and hatcheries (open circles) for the Mid and Upper Columbia River summer/fall Chinook salmon (Oncorhynchus tshawytscha) population (modified from Weissenborn 1969; river abbreviations referenced in Table 1). Okanagon (OKA) and Similkameen (SIM) rivers have summer-run Chinook salmon populations not sampled in this study. Surficial geology in the upper Columbia River watershed varies in age and lithology ranging from young (Cenozoic) volcanic rocks (light pink, orange and brown) in the Columbia Basin and Southern Cascades, older granitic rocks (red) and metamorphic rocks (purple) in the Northern Cascades, to varying ages of sedimentary rocks with the oldest rocks in the state found in the East Okanogan Highlands (blue and dark green) 
Chinook salmon, Feyrer et al. (2007) on Splittail (Pogonichthys macrolepidotus), Bradbury et al. (2008) on Rainbow Smelt (Osmerus mordax), and Planes et al. (2009) on Clown Fish (Amphiprion percula) have combined genetic and otolith elemental analyses on the same individuals. Chinook salmon in the Mid and Upper Columbia River watershed are an ideal species and system to develop an integrated genetic and otolith microchemistry approach because (1) limited genetic differentiation occurs among rivers within the UCR $\mathrm{Su} / \mathrm{F}$ population, yet restoration and management actions occur at finer-scales of natal sources (Waples et al. 2001), (2) high diversity in watershed geology exists, establishing a mechanistic foundation for variation in ${ }^{87} \mathrm{Sr} /{ }^{86} \mathrm{Sr}$ markers at small spatial scales, and (3) populations of Chinook salmon are of economic value and conservation concern.

An integrated baseline of isotopic and genetic information may act synergistically to improve assignment probabilities where stocks co-occur in estuarine and marine systems. Several Chinook salmon ESUs show gene flow at the scale of natal sources while ${ }^{87} \mathrm{Sr} /{ }^{86} \mathrm{Sr}$ are likely to be limited as broad spatial scale markers due to natal sources having similar ${ }^{87} \mathrm{Sr} /{ }^{86} \mathrm{Sr}$ in other watersheds along the species' distribution. In this study, we characterize for the first time the ${ }^{87} \mathrm{Sr} /{ }^{86} \mathrm{Sr}$ values of natal sources of summer and fall run Chinook salmon from the Mid and Upper Columbia River population and examine the utility of using genetic and isotopic information as natural population markers on the same individuals to identify broad (e.g., regional genetic stock groups/ ESUs) and fine-scale (natal source) populations.

\section{Methods}

Our approach to exploring the use of $\mathrm{Sr}$ isotopes and genetic information to identify the natal sources of Chinook salmon was to first establish a baseline of ${ }^{87} \mathrm{Sr} /{ }^{86} \mathrm{Sr}$ ratios in the otoliths collected from each natal source. Then we characterized the variation in microsatellite DNA from the same individuals and natal sources. Finally, to assess the utility of integrating genetic and isotopic markers at different scales of population structure, we used a step-wise hierarchy approach by: (1) testing the accuracy of a pre-existing coast wide microsatellite DNA baseline to identify individuals to the UCR Su/F genetic group (Seeb et al. 2007), (2) testing the accuracy of our ${ }^{87} \mathrm{Sr} /{ }^{86} \mathrm{Sr}$ baseline to identify fish to natal sources within the UCR $\mathrm{Su} / \mathrm{F}$ genetic group, and (3) compared the accuracy of the coast wide genetic baseline to identify individuals to natal sources present in the genetic baseline, with the results using ${ }^{87} \mathrm{Sr} /{ }^{86} \mathrm{Sr}$.

\section{Study system}

The native populations of summer and fall run Chinook salmon in the Columbia River above the confluence with the Snake River comprise the UCR $\mathrm{Su} / \mathrm{F}$ ESU (Myers et al. 1998). This is one of eight ESUs of Chinook salmon that have been identified within the Columbia River Basin based on a synthesis of genetic, life-history, biogeographic, geologic, and environmental information (Myers et al. 1998). The boundaries of the ESU are the Grand Coulee Dam upstream and down-river at the crest of the Cascade Range. Most of the current natural production of fish in the UCR are summer run populations in the Wenatchee, Methow, Okanagon, and Similkameen rivers and fall run populations in the Yakima and Klickitat rivers and in the mainstem Columbia River in the Hanford Reach area (Waknitz et al. 1995, Myers et al. 1998; Fig. 1). Large hatchery programs associated with these populations also release summer and fall run fish in the Upper and Mid Columbia River (Table 1).

The Columbia River watershed is characterized by complex and heterogeneous geology. There are several physiographic regions that influence the geochemistry of the Upper and Mid Columbia River including Okanogan Highlands, Northern and Southern Cascade Mountains, and the Columbia Basin. The geochemistry of the water where fish rear in the wild is derived from weathering of rocks within the entire upstream watershed. The Okanogan Highlands contain the oldest sedimentary and metamorphic rocks in the state, which influence the ${ }^{87} \mathrm{Sr} /{ }^{86} \mathrm{Sr}$ values in the mainstem waters of the Columbia River (Lasmanis 1991). The northwestern portion of the upper Columbia River watershed receives freshwater input from the Northern Cascade Mountains composed primarily of Mesozoic crystalline and metamorphic rocks. The Southern Cascades are younger Tertiary and Holocene volcanic rocks (Lasmanis 1991; Fig. 1). Most of the salmon-bearing tributaries to the Columbia 
Table 1 Sample information, ${ }^{87} \mathrm{Sr} /{ }^{86} \mathrm{Sr}$ values, standard deviation (SD), and results of the linear discriminant function analysis using a jack-knife approach to classify Chinook salmon (Oncorhynchus tshawytscha) to natal population based on ${ }^{87} \mathrm{Sr} /{ }^{86} \mathrm{Sr}$ values

\begin{tabular}{|c|c|c|c|c|c|c|c|c|}
\hline $\begin{array}{l}\text { Natal collection site; abbreviation } \\
\text { (code) }\end{array}$ & River & Run $^{1}$ & $\begin{array}{l}\text { Collection } \\
\text { year }\end{array}$ & $\begin{array}{l}\text { Rearing } \\
\text { type }\end{array}$ & ${ }^{87} \mathrm{Sr} /{ }^{86} \mathrm{Sr}$ & SD & $\mathrm{N}$ & $\begin{array}{l}\text { Classification } \\
\text { accuracies } \\
\% \text { correct }\end{array}$ \\
\hline 1. Methow River (MET) & Methow & SU & 2007 & Natural & 0.70432 & 0.00011 & 8 & 100 \\
\hline 2. Klickitat Hatchery (KLI) & Klickitat & $\mathrm{F}$ & 2008 & Hatchery & 0.70568 & 0.00018 & 10 & 50 \\
\hline 3. Wenatchee River (WEN) & Wenatchee & SU & 2007 & Natural & 0.70572 & 0.00016 & 10 & 30 \\
\hline 4. Yakima River (YAK) & Yakima & $\mathrm{F}$ & 2008 & Natural & 0.70577 & 0.00024 & 10 & 20 \\
\hline 5. Little White Salmon Hatchery (LWS) & L. White Salmon & $\mathrm{F}$ & 2007 & Hatchery & 0.70606 & 0.00022 & 10 & 0 \\
\hline 6. Prosser Hatchery (PRO) & Yakima & $\mathrm{F}$ & 2008 & Hatchery & 0.70604 & 0.00039 & 8 & 25 \\
\hline 7. Bonneville Hatchery (BON) & mainstem & $\mathrm{F}$ & 2007 & Hatchery & 0.70818 & 0.00013 & 10 & 100 \\
\hline 8. Umatilla Hatchery (UMA) & mainstem & $\mathrm{F}$ & 2008 & Hatchery & 0.71058 & 0.00012 & 11 & 82 \\
\hline 9. Wells Hatchery (WEL) & mainstem & SU & 2007 & Hatchery & 0.71080 & 0.00015 & 11 & 55 \\
\hline 10. Eastbank Hatchery (EBH) & mainstem & SU & 2007 & Hatchery & 0.71113 & 0.00023 & 10 & 50 \\
\hline 11. Priest Rapids Hatchery (PRH) & mainstem & $\mathrm{F}$ & 2007 & Hatchery & 0.71154 & 0.00023 & 10 & 70 \\
\hline 12. Hanford Reach (HAN) & mainstem & $\mathrm{F}$ & 2007 & Natural & 0.71415 & 0.00012 & 9 & 100 \\
\hline
\end{tabular}

Jack-knife classification accuracies and overall mean classification accuracies. ${ }^{1}$ Progeny of fish returning to spawn in the summer (SU) and fall (F), except for adults sampled at Hanford Reach

River drain the Southern Cascades or the Columbia Basin province comprised of basalt from the Miocene. This Columbia River Basalt group is characterized by several hundred individual flows that amount to $\sim 234$ $000 \mathrm{~km}^{3}$ of tholeiitic basalt, and andesite lava flows covering large areas including south central and eastern Washington along the Columbia River (Hooper 1997; Camp et al. 2004). This diverse surficial geology results in a wide range of ${ }^{87} \mathrm{Sr} /{ }^{86} \mathrm{Sr}$ values among Columbia River tributaries (Ramos et al. 2006; Singleton et al. 2006; Fig 1)

\section{Natal source signatures}

To develop a baseline of ${ }^{87} \mathrm{Sr} /{ }^{86} \mathrm{Sr}$ ratios across natal sources and acquire genotypes from individuals within the natal sources, otoliths and tissues were collected from sub-yearling juvenile Chinook salmon between May-August from seven hatcheries and five naturally spawning populations in 2007 and 2008 (Table 1). Wild juveniles ( $55 \mathrm{~mm}$ fork length) were collected from streams with rotary screw traps operated by Yakama Nation Fisheries and Washington Department of Fish and Wildlife. Wild juveniles were assumed to originate from the streams where they were collected based on their small sizes and general downstream migration behavior out of tributaries. Hanford Reach, on the mainstem Columbia River, is known to be an area of active spawning and juvenile rearing. Yet juveniles collected from this location could represent out-migrants from several potential upstream rivers. Thus, to characterize the Hanford Reach natal site, we collected adults spawning at Hanford Reach in November of 2007 and analyzed the natal portion of adult otoliths. This approach assumes spawning fidelity to the site of origin and was later supported by the low variance in ${ }^{87} \mathrm{Sr} /{ }^{86} \mathrm{Sr}$ values characteristic of individuals at this site.

\section{Genetic}

Genomic DNA was extracted from fin tissue samples using Wizard genomic DNA purification kits (Promega Corp.) following the manufacturer's protocols. Isolated genomic DNA was amplified via the polymerase chain reactions (PCR) at 13 microsatellite loci using the standardized protocols discussed by Seeb et al. (2007). The resulting PCR products were analyzed with an Applied Biosystems 3100 capillary electrophoresis system. GeneScan and Genotyper software (Applied Biosystems) were used to determine the size and number of alleles observed at each locus. 


\section{Isotopic}

Sagittal otoliths were extracted, washed, and stored in dry vials prior to cleaning and mounting. The left otolith was soaked for $6 \mathrm{~h}$ in $30 \%$ Suprapur ${ }^{\circledR} \mathrm{H}_{2} \mathrm{O}_{2}$ to remove organic material and double rinsed in ultrafiltered water. The right otolith was used if the left otolith was compromised during preparation or composed of the vaterite form of calcium carbonate. Otoliths were mounted sulcus side up on microscope slides and polished using $\mathrm{Al}_{2} \mathrm{O}_{3}$ lapping paper until daily increments were revealed (Barnett-Johnson et al. 2005). Otoliths were transferred and grouped onto clean petrographic slides, randomized by source location and sampled using $60 \times 500 \times 80 \mu \mathrm{m}(\mathrm{W} \times$ $\mathrm{L} \times \mathrm{D})$ laser tracks in the dorsal region along the longest axis parallel to daily increments $(5 \mu \mathrm{m}$ increment $^{-1}$; $\sim 12$ days) where the plane of growth exhibits the least curvature (Barnett-Johnson et al. 2005). We measured ${ }^{87} \mathrm{Sr} /{ }^{86} \mathrm{Sr}$ in the region of the otolith accreted while in the natal tributary or hatchery, but after yolk absorption and prior to outmigration ( $250 \mu \mathrm{m}$ from primordia). This region was just distal to the dark band diagnostic of the onset of exogenous feeding (Barnett-Johnson 2007). Isolating this region is particularly important when characterizing natal ${ }^{87} \mathrm{Sr} /{ }^{86} \mathrm{Sr}$ values, because the prefeeding value reflects $\mathrm{Sr}$ derived from both marine (maternally inherited) and natal river sources (Bacon et al. 2004; Miller and Kent 2009).

Otolith ${ }^{87} \mathrm{Sr} /{ }^{86} \mathrm{Sr}$ data were collected using a NuPlasma HR multi-collector inductively coupled plasma mass spectrometer (MC-ICPMS) coupled to a Nd:YAG $213 \mathrm{~nm}$ laser (New Wave UP213; with a SuperCell ${ }^{\mathrm{TM}}$ sample chamber) with specific instrument, laser, and interference corrections described in Ramos et al. (2004) as applied to otoliths (BarnettJohnson et al. 2005). All monitored isotopes were collected simultaneously and integrated for $2 \mathrm{~s}$. Approximately thirty ${ }^{87} \mathrm{Sr} /{ }^{86} \mathrm{Sr}$ ratios were measured for each laser track and used to estimate within-run precision for each otolith $(2 \times$ standard error \pm 0.00004). The laser ablated the otolith using a $20 \mathrm{~Hz}$ pulse-rate and moved at a rate of $10 \mu \mathrm{m} \cdot \mathrm{s}^{-1}$, removing material along a $60 \mu \mathrm{m}$ wide transect $500 \mu \mathrm{m}$ in length. While there are several potential interferences on $\mathrm{Sr}$ isotopes in carbonates, including $\mathrm{Ca}$ dimers, $\mathrm{Ca}$ argides and doubly-charged $\mathrm{Er}$ and $\mathrm{Yb}$, only $\mathrm{Rb}$ and $\mathrm{Kr}$ affected the accuracy and precisions of ${ }^{87} \mathrm{Sr} /{ }^{86} \mathrm{Sr}$ (Barnett-Johnson et al. 2005). We accounted for the effects of ${ }^{84} \mathrm{Kr}$ and ${ }^{86} \mathrm{Kr}$, present in the $\mathrm{Ar}$ gas by subtracting on-peak baselines $\left(<1 \mathrm{mV}{ }^{83} \mathrm{Kr}\right.$ ) measured prior to ablation of otoliths from beam intensities during otolith ablation. To correct for ${ }^{87} \mathrm{Rb}$, we used the measured ${ }^{86} \mathrm{Sr} /{ }^{88} \mathrm{Sr}$ and natural ${ }^{85} \mathrm{Rb} /{ }^{87} \mathrm{Rb}$ value to calculate a mass bias uncorrected ${ }^{85} \mathrm{Rb} /{ }^{87} \mathrm{Rb}$ ratio and the measured ${ }^{85} \mathrm{Rb}$ intensity to calculate and remove any ${ }^{87} \mathrm{Rb}$ contributions to measured ${ }^{87} \mathrm{Sr}$ intensities. ${ }^{87} \mathrm{Sr} /{ }^{86} \mathrm{Sr}$ ratios were then normalized to ${ }^{88} \mathrm{Sr} /{ }^{86} \mathrm{Sr}=0.1194$ to account for any natural or machine induced fractionation. External precisions (reproducibility) were based on repeated measurements of our in-house gastropod shell standard. The mean (SD) value of ${ }^{87} \mathrm{Sr} /{ }^{86} \mathrm{Sr}$ measurements for the standard was 0.70922 (0.00004; $n=417)$, which is close to the global marine ${ }^{87} \mathrm{Sr} /{ }^{86} \mathrm{Sr}$ value of 0.70918 .

Sr isotope ratios among natal sources were compared using analysis of variance (ANOVA) with Bonferroni post-hoc pairwise comparisons, to determine whether there were significant differences in the means in isotopic signatures among sources. Strontium isotope values met the assumptions of normality for ANOVA, but did not have equal variances among locations.

\section{Genetic-isotope assignment hierarchy}

We conducted our assignments using genetic and isotopic information in a hierarchical manner, similar to a method one may use in a realistic unknown mixture analysis for salmon. First, Chinook salmon genotyped in this study (Table 1) were assigned to genetic stock groups using microsatellite data compiled from a pre-existing coast wide genetic baseline representing 141 populations from Southeast Alaska to California described by Seeb et al. (2007). This baseline estimates the likely regional genetic stock group as well as population (e.g., natal origin) within the regional stock groups for each individual genotyped. We used the likelihood model of Rannala and Mountain (1997) as implemented by the genetic stock identification computer program ONCOR (Kalinowski et al. 2007). Posterior assignment probabilities for individual baseline sources were summed to regional genetic stock groups, the scale for which there is greater assignment accuracy (see Seeb et al. 2007). We used equal priors in our genetic assignments even though fish in this study did not have a random 
chance of being part of the broader baseline. In an unknown mixture analysis, one would assume equal priors and only individuals assigned to the UCR Su/F genetic group with high posterior probabilities would be evaluated using this ${ }^{87} \mathrm{Sr} /{ }^{86} \mathrm{Sr}$ baseline. However, since all samples collected for this study were known to originate from the UCR $\mathrm{Su} / \mathrm{F}$ region, we retained all individuals in the isotope model.

Second, Chinook salmon were assigned to their natal origins using a single factor linear discriminant function analysis (DFA) with jackknife resampling to determine whether ${ }^{87} \mathrm{Sr} /{ }^{86} \mathrm{Sr}$ values alone could be used to correctly classify individual fish to natal origin (SAS version 8, SAS Institute Inc., Cary, New York). A linear function was used to estimate the variance-covariance matrix response and applied across all sites. Jackknife resampling used the same data set to generate and evaluate the discriminant function by removing an observation and reclassifying it to the source with the closest mean ${ }^{87} \mathrm{Sr} /{ }^{86} \mathrm{Sr}$ value. This procedure was repeated for all observations to determine correct assignment percentages for each natal source. Prior probability of group membership was assumed to be proportional.

To identify natal sources and groups with similar ${ }^{87} \mathrm{Sr} /{ }^{86} \mathrm{Sr}$ values, we conducted a cluster analysis (PRIMER version 6.1.5 software; Plymouth Routines in Multivariate Ecological Research; SIMPROF test). Cluster analysis used normalized ${ }^{87} \mathrm{Sr} /{ }^{86} \mathrm{Sr}$ for all fish in the study to generate a similarity matrix of Euclidean distances and implemented a hierarchical agglomerative clustering routine using the group average to determine the similarity of ${ }^{87} \mathrm{Sr} /{ }^{86} \mathrm{Sr}$ values among natal sources. The SIMPROF test was used to determine actual structure in the subset of data corresponding to each branch by calculating the distance between clusters of the dendrogram using 1000 permutations.

The pre-existing microsatellite baseline contains genotypes from approximately 150 individuals from each of four natal sources within the UCR Su/F regional genetic stock group also represented in this studyMethow River summer, Hanford Reach fall, Wells Hatchery summer, and upper Wenatchee summer/fall. Therefore, we compared the accuracies of fine-scale (natal source) assignments between the genetic and ${ }^{87} \mathrm{Sr} /{ }^{86} \mathrm{Sr}$ baselines for fish from these four sources.

\section{Results}

The vast majority of Chinook salmon in our study were assigned to the UCR $\mathrm{Su} / \mathrm{F}$ genetic stock group with strong group membership using the coast wide microsatellite baseline. The strength of assignment (posterior probability) for all individuals in this study averaged $92 \%$ (standard deviation $(\mathrm{SD})=13$ ). Of 86 individuals with assignment probabilities $>0.90,84$ were correctly assigned to the UCR $\mathrm{Su} / \mathrm{F}$ group. Of 32 fish with probabilities $<0.90,15$ were correctly identified (Fig. 2). Individuals assigned to non-UCR $\mathrm{Su} / \mathrm{F}$ groups had an average posterior probability of assigning to the UCR $\mathrm{Su} / \mathrm{F}$ of $0.25(S D=0.15)$. Most of the incorrect assign-
Fig. 2 Estimated genetic stock of origin and posterior probabilities of assignments for 118 upper Columbia River summer and fall Chinook salmon using 13 standardized microsatellite DNA loci. Stock groups are Upper Columbia River Summer and fall (UCR Su/F), Snake River fall (Snake F), and 30 groups ranging from California to southern British Columbia (Other)

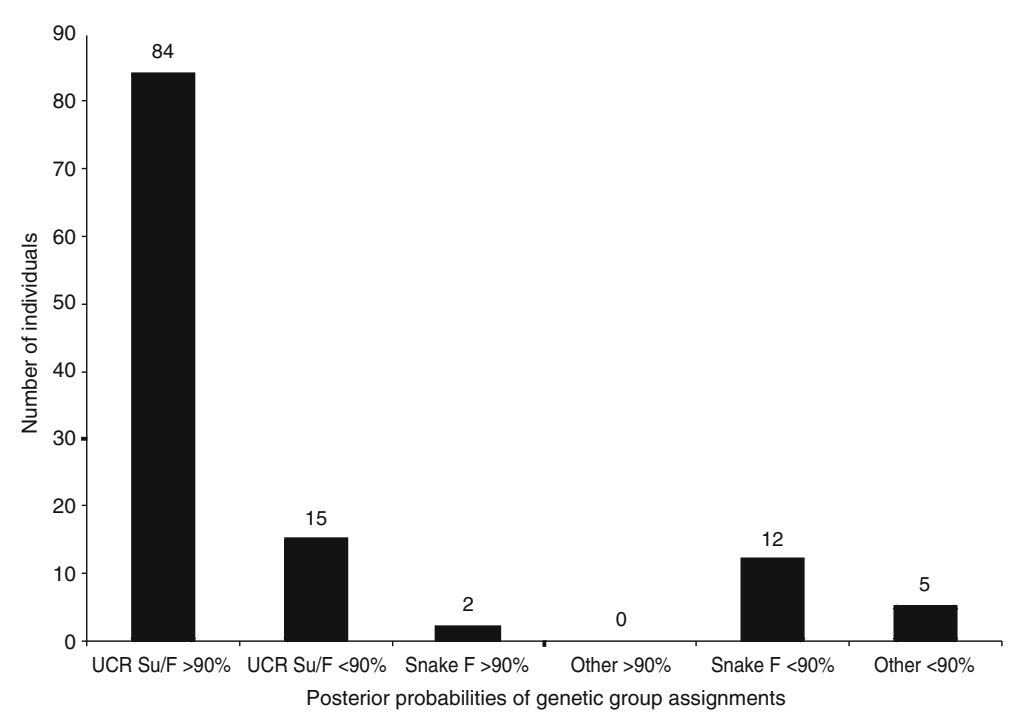


ments were to the genetically related Snake and Deschutes Fall-run. Five of the low probability fish were not assigned to the Columbia River (Fig. 2).

${ }^{87} \mathrm{Sr} /{ }^{86} \mathrm{Sr}$ values were significantly different across natal sources and ranged in values from $0.7043-$ 0.7142 (ANOVA, $F_{11,104}=2345, p<0.001$ ). The ${ }^{87} \mathrm{Sr} /{ }^{86} \mathrm{Sr}$ model showed that all 58 pairwise comparisons were significantly different $(d f=105, p<0.05)$ with the exception of eight comparisons (Klickitat Hatchery (KLI) with Wenatchee River (WEN) and Yakima River (YAK); Little White Salmon Hatchery (LWS) with Yakima River (YAK) and Prosser Hatchery (PRO); Umatilla Hatchery (UMA) and Wells Hatchery (WEL); PRO with WEN and YAK; and WEN and YAK; Table 1). Discriminant function analysis for the ${ }^{87} \mathrm{Sr} /{ }^{86} \mathrm{Sr}$ only model resulted in classifications that ranged from 0 to $100 \%$ (Wilks's Lambda, $\left.F_{11,105}=2344, p<0.001\right)$. All individuals from three natal sources were correctly assignedMethow River (MET); Bonneville Hatchery (BON); and Hanford Reach (HAN), with only two individuals from UMA misclassified (82\%; Fig. 3). Fish from KLI, WEN, YAK, LWS, PRO, WEL, EBH, and PRH had lower assignment success (Table 1). Some natal sources (e.g., Okanagon (OKA) and Similkameen (SIM) were not included in the ${ }^{87} \mathrm{Sr} /{ }^{86} \mathrm{Sr}$ baseline. This may influence the strength of assignment for some natal sources.

The similarity dendrogram from the cluster analysis shows that ${ }^{87} \mathrm{Sr} /{ }^{86} \mathrm{Sr}$ resolved fine-scale assignments to three individual natal sources (MET, BON, and HAN), and two more regional groups with $100 \%$ correct classification success (Fig. 4). The two regional groups were comprised of mainstem hatchery sources (WEL, EBH, PRH, UMA) and sources located on tributaries to the Columbia River (WEN, YAK, PRO, KLI, LWS).

Of the 34 samples in our study from the four sources represented in the pre-existing microsatellite DNA baseline (MET, WEL, HAN, WEN) 31 (91\%) were correctly assigned to the UCR $\mathrm{Su} / \mathrm{F}$ genetic stock group. However, only about $1 / 3$ of the fish from these four sources were assigned to the correct natal source using the entire coast-wide genetic baseline (Fig. 5). Individuals appeared randomly misassigned to non-natal sources. A significantly greater proportion of the 34 samples (approximately 2/3) were correctly assigned to their natal source using the ${ }^{87} \mathrm{Sr} /{ }^{86} \mathrm{Sr}$ baseline. The lower assignment success of individuals to their correct natal sources using the genetic baseline highlights its limitation at finer scales. In contrast, the ${ }^{87} \mathrm{Sr} /{ }^{86} \mathrm{Sr}$ baseline significantly improved classification success of individuals originating from three of the four natal sources. Assignments improved from (25 to $100 \%)$, (40 to 64\%), (33 to $100 \%$ ) for individuals from MET, WEL, HAN respectively (Fig. 5). Assignment success for individuals from WEN remained the same $(30 \%)$ with the inclusion of ${ }^{87} \mathrm{Sr} /{ }^{86} \mathrm{Sr}$ information.

\section{Discussion}

This study provides support for the integration of otolith microchemistry and multilocus genotypes to provide broad (e.g., basin/ESU) and finer scale (e.g., natal source) identities for Chinook salmon. There is a long history and continued effort in the fisheries
Fig. $3{ }^{87} \mathrm{Sr} /{ }^{86} \mathrm{Sr}$ values in the natal growth region of otoliths from Chinook salmon (Oncorhynchus tshawytscha) collected in rivers and hatcheries in the upper Columbia River. Natal river codes correspond to populations listed in Table 1

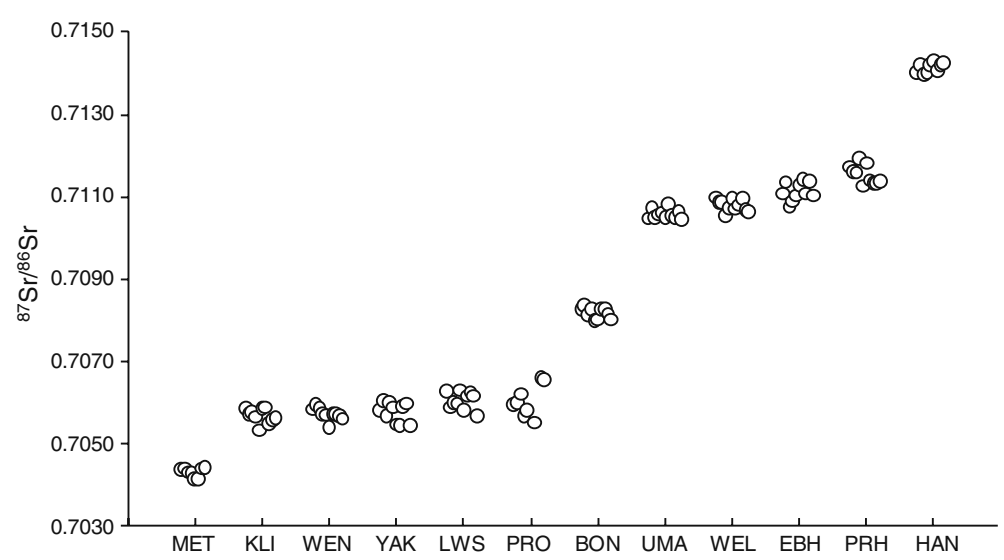




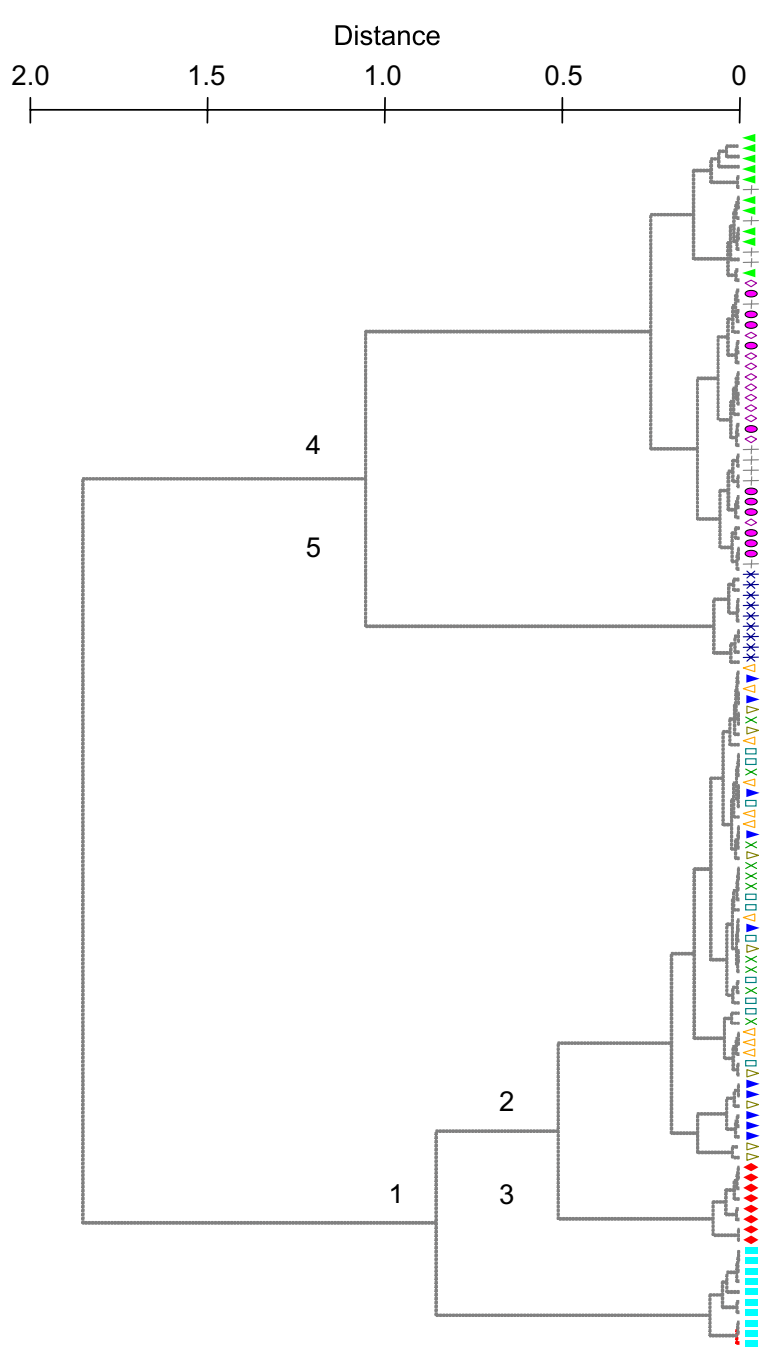

Fig. 4 Similarity dendrogram using normalized ${ }^{87} \mathrm{Sr} /{ }^{86} \mathrm{Sr}$ values for all individuals and a similarity matrix of Euclidean distances with a group average algorithm. Individuals originated from the summer/fall Chinook salmon from Mid and Upper Columbia River tributaries- MET $(\Delta), \operatorname{WEN}(\times), \operatorname{YAK}(\triangle)$, LWS ( $\nabla)$, KLI $(\square)$, PRO $(\nabla)$, and mainstem Columbia RiverHAN $(\star)$, BON $(\square)$, UMA $(\diamond)$, WEL $(\bigcirc)$, EBH $(+)$, PRH $(\triangle)$. Natal river and hatchery codes are referenced in Table 1. Five distinct groups (numbered) are identified with 100\% correct classification success. Groups 1, 2, and 4 are resolved to individual natal sources whereas groups 3 and 5 reflect natal sources on tributaries and the mainstem Columbia River respectively

literature on documenting biological attributes that differ among stocks as intrinsic markers to minimize the need for expensive and laborious physical tags (Marques et al. 2006; Abaunza et al. 2008; MacKenzie 2009). For example, many salmonid stocks can be distinguished based on unique scale or otolith struc- ture (Henry 1961; Marshall et al. 1987; BarnettJohnson 2007), morphometric and meristic characters (Fukuhara et al. 1962; Winans 1984; MacCrimmon and Claytor 1985), parasites (Margolis 1963; Bailey and Margolis 1987), and genetic differences (Utter et al. 1987; Winans et al. 2001). Recent studies have explored integrating multiple biological markers in salmon with varying levels of success and resolution (Wood et al. 1989; Barnett-Johnson et al. 2008; Narum et al. 2008). Specifically, none have achieved a resolution that easily scales between local natal sources and regional populations applicable to mixedstock groups at fine-scale resolution.

Molecular markers have previously been used to identify the genetic origins of Chinook salmon in mixed-stock ocean fisheries at broad scales with great success (Winans et al 2001; Beacham et al. 2006). The majority (84\%) of Chinook salmon in this study were correctly identified to the UCR Su/F genetic stock group using a standardized microsatellite dataset. However, assignment success of natal sources nested within the UCR $\mathrm{Su} / \mathrm{F}$ population was poor. This is likely due to naturally occurring gene flow among

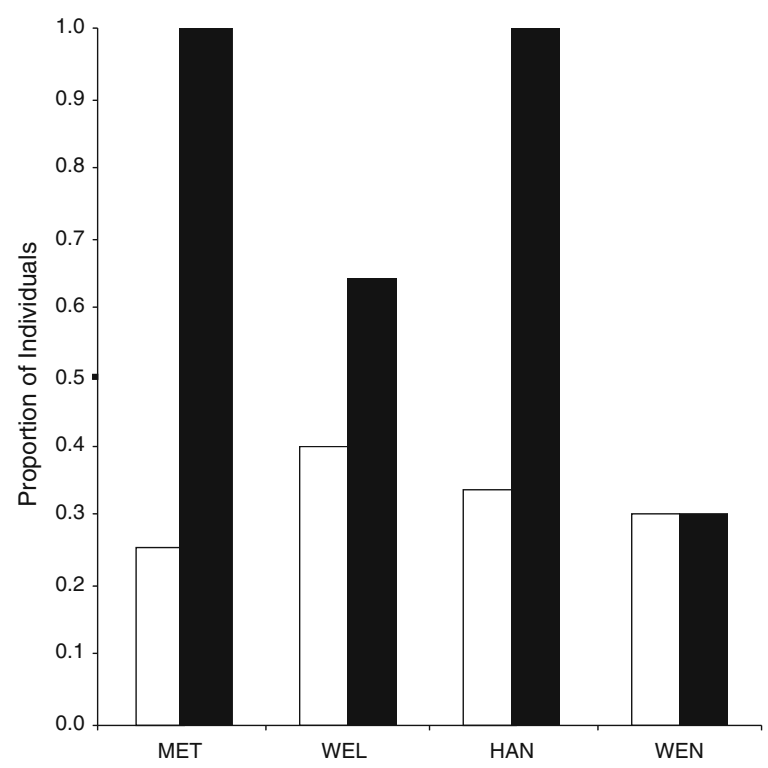

Fig. 5 Proportion of Chinook salmon (Oncorhynchus tshawyt$s c h a$ ) correctly identified as originating from their natal capture site using a coast wide microsatellite DNA baseline (open bars) and ${ }^{87} \mathrm{Sr} /{ }^{86} \mathrm{Sr}$ values (filled bars). Results for four populations represented in both this study and in the coast wide microsatellite DNA baseline are shown. Natal river codes correspond to populations listed in Table 1 
natal sources over short temporal and spatial scales as well as alterations in migration and spawning habitat, and among basin transfers of broodstocks for hatchery operations (see also Seeb et al. 2007; Narum et al. 2008). There is a growing need to identify specific natal sources to better understand salmon ocean ecology and to monitor recovery efforts that occur at the scale of individual rivers.

Previous studies have highlighted the utility of using ${ }^{87} \mathrm{Sr} /{ }^{86} \mathrm{Sr}$ to differentiate natal habitats at local scales (Kennedy et al. 1997; Ingram and Weber 1999; Hobbs et al. 2005). We found a wide range in ${ }^{87} \mathrm{Sr} /{ }^{86} \mathrm{Sr}$ values present among natal sites in the Mid and Upper Columbia River basin, which was 1.5 times greater than that observed among California's Central Valley rivers and hatcheries (Barnett-Johnson et al. 2008). The small errors around our population mean ${ }^{87} \mathrm{Sr} /{ }^{86} \mathrm{Sr}$ value suggests that individuals collected in our study were likely born or spent a significant amount of time rearing at the specific location of collection. Three sites (MET, BON, and HAN) had ${ }^{87} \mathrm{Sr} /{ }^{86} \mathrm{Sr}$ that were unique allowing for unequivocal assignment of individuals to correct natal locations.

We found general trends in ${ }^{87} \mathrm{Sr} /{ }^{86} \mathrm{Sr}$ values along the Columbia River and its tributaries that corresponded to surficial geology in the watershed. The mainstem Columbia River is influenced at its headwaters in Washington by old Paleozoic sedimentary rocks in the eastern Okanogan Highlands (Lasmanis 1991; Fig. 1). The Hanford Reach site (HAN) represents our only natural source of Chinook salmon on the mainstem and had the most radiogenic ${ }^{87} \mathrm{Sr} /{ }^{86} \mathrm{Sr}$ value $(0.7142)$. This ${ }^{87} \mathrm{Sr} /{ }^{86} \mathrm{Sr}$ value is consistent with previous Columbia River water values and Columbia River Basalt Group values of 0.7034 in early-erupted basalts to 0.7145 in late-erupted flows (Ramos et al. 2006; Singleton et al. 2006). Four hatcheries (WEL, EBH, PRH, UMA) on the mainstem have similar ${ }^{87} \mathrm{Sr} /{ }^{86} \mathrm{Sr}$ ratios that are less radiogenic than HAN but show greater than ocean ${ }^{87} \mathrm{Sr} /{ }^{86} \mathrm{Sr}$ values (Table 1). This pattern is consistent with the influence of marine-derived feed on the ${ }^{87} \mathrm{Sr} /{ }^{86} \mathrm{Sr}$ in the otoliths of hatchery fish reflecting a mixture of the ${ }^{87} \mathrm{Sr} /{ }^{86} \mathrm{Sr}$ in source water on the mainstem Columbia River and less radiogenic ${ }^{87} \mathrm{Sr} /{ }^{86} \mathrm{Sr}$ value of hatchery feed $(0.70918$; Ingram and Weber 1999). Hatchery feed could affect otolith ${ }^{87} \mathrm{Sr} /{ }^{86} \mathrm{Sr}$ through dietary source of $\mathrm{Sr}$ or altered dissolved ambient Sr in the water (Barnett-Johnson et al. 2008).
Natal sources located along the tributaries to the west of the Columbia River and south of the Methow River (WEN, YAK, PRO, KLI, LWS) have similar ${ }^{87} \mathrm{Sr} /{ }^{86} \mathrm{Sr}$ values $(\sim 0.706)$. The ${ }^{87} \mathrm{Sr} /{ }^{86} \mathrm{Sr}$ values characterizing these tributary sources are influenced by the younger Miocene volcanic formations in the Columbia Basalt Group and the Southern Cascade Mountain range (Lasmanis 1991; Fig. 1). The Bonneville Hatchery isotopic signature $(0.70818)$ is intermediate between the mainstem Columbia River and upstream tributary values. This result is consistent with the isotopic mixing of these waters.

For the few studies that have used both molecular genetic and otolith microchemical information on the same individuals, significant insight has been gained about the spatial scales of connectivity (Milton and Chenery 2001; Miller et al. 2005; Bradbury et al. 2008). The variation in otolith ${ }^{87} \mathrm{Sr} /{ }^{86} \mathrm{Sr}$ performs at its best when integrated with other data and approaches (Harrington et al. 1998; Barnett-Johnson et al. 2008). ${ }^{87} \mathrm{Sr} /{ }^{86} \mathrm{Sr}$ values are unlikely to be unique among natal sources across a species' distribution. Without a marker identifying individuals to broader geographic regions, the ${ }^{87} \mathrm{Sr} /{ }^{86} \mathrm{Sr}$ marker may be of limited utility for many fisheries applications where stocks co-occur. For example, Chinook salmon from the Yuba River in California's Central Valley and from the Bonneville Hatchery in the Columbia River basin have similar ${ }^{87} \mathrm{Sr} /{ }^{86} \mathrm{Sr}$ values $(\sim 0.70818$; Barnett-Johnson et al. 2008). However, the California Central Valley and Columbia River stocks differ genetically (Seeb et al. 2007). Harrington et al. (1998) used variation in $\delta^{15} \mathrm{~N}$ among watersheds due to agricultural influences with ${ }^{87} \mathrm{Sr} /{ }^{86} \mathrm{Sr}$ to further delineate Atlantic Salmon (Salmo salar) rearing habitats. (Walther and Thorrold 2008) used oxygen isotopes that varied broadly along a latitudinal gradient of precipitation in conjunction with $\mathrm{Sr} / \mathrm{Ca}, \mathrm{Ba} / \mathrm{Ca}$, and ${ }^{87} \mathrm{Sr} /{ }^{86} \mathrm{Sr}$ in otoliths to characterize the freshwater natal rearing sites of American Shad (Alosa sapidissima) along the entire U.S. Atlantic coast.

Many Pacific salmon populations are demographically independent and exhibit stock-specific extinction risks. Identifying individual stocks in mixed-stock harvest management is fundamental for preventing overexploitation of vulnerable stocks while optimizing the harvest of abundant populations. The need for a coordinated coast-wide effort in stock identification for Pacific salmon has long been 
recognized, but the search for the ideal biological markers continues to evolve as new stock identification techniques and statistical approaches emerge (Wood et al. 1989; Seeb et al. 2007). Wood et al. (1989) evaluated the accuracy and precision of stock composition estimates of sockeye salmon using 51 principal stocks in British Columbia and Southeast Alaska with four types of biological markers- freshwater age, six scale pattern variables, the prevalence of a brain parasite, and five genetic (electrophoretic) traits. They concluded that in general, estimates for individual stocks are unreliable using these markers largely due to the annual variability in scale patterns, and lack of genetic or stable parasite markers to achieve desired levels of stock resolution.

Our integrated approach shows promise in addressing outstanding questions in salmon ecology and the potential for application at the coast-wide scale. The low annual variation in both the microsatellite and ${ }^{87} \mathrm{Sr} /{ }^{86} \mathrm{Sr}$ markers minimizes the frequency of new baseline data collection. An additional benefit to developing ${ }^{87} \mathrm{Sr} /{ }^{86} \mathrm{Sr}$ baselines is that multiple fish species occupying the same systems can be tracked using the same ${ }^{87} \mathrm{Sr} /{ }^{86} \mathrm{Sr}$ signatures of origin. For example, several rivers from Japan to California have multiple species of salmon-Chinook, Steelhead $(O$. mykiss) Coho (O. kisutch), and Sockeye (O. nerka). Developing a baseline of ${ }^{87} \mathrm{Sr} /{ }^{86} \mathrm{Sr}$ natal values within a river system could improve the management and conservation of several salmon species. Sophisticated genetic baselines (microsatellite and SNPs) are currently being considered by fisheries resource managers as integral tools to minimize mortality on protected stocks, and target healthy populations in the ocean fisheries (see Seeb et al. 2007). The development of ${ }^{87} \mathrm{Sr} /{ }^{86} \mathrm{Sr}$ baselines for individual rivers and hatcheries within key ESUs would allow for finer-scale identities in systems where molecular markers show limited resolution. Genetic tools alone could provide natal source identities or even finerresolution (e.g., parentage) in some systems, but would require sampling each brood year, examination of more loci, and expensive and labor intensive efforts (Hauser et al. 2006; Planes et al. 2009). ${ }^{87} \mathrm{Sr} /{ }^{86} \mathrm{Sr}$ and microsatellite baselines have been developed for rivers and hatcheries within the UCR $\mathrm{Su} / \mathrm{F}$ and California's Central Valley fall ESUs, two significant populations to west-coast salmon fisheries (BarnettJohnson et al. 2008; Weitkamp 2010). Next steps would be to apply these tools for mixed collections of juveniles or adults in estuaries and coastal oceans to better understand source-specific distributions and individual growth and condition.

The need for reliable stock identification tools will continue to grow as recovery efforts for salmon stocks listed under the Endangered Species Act intensify. Our results suggest that integrating molecular genetic and otolith isotopic data in a Bayesian framework may be the next step in its application to coast-wide salmon conservation and harvest management for these stocks. Genetic stock identification programs can produce rapid turn-around times useful for real-time fisheries management decisions. To date, otolith ${ }^{87} \mathrm{Sr} /{ }^{86} \mathrm{Sr}$ measurements have provided retrospective insights, but could achieve comparable efficiencies with significant resources and advances in mass spectrometry. The development of additional baselines of ${ }^{87} \mathrm{Sr} /{ }^{86} \mathrm{Sr}$ variation within key genetic groups may provide fine-scale resolution in other salmon systems. In addition, other biological markers (e.g., otolith elemental ratios) may provide still further resolution for natal sources that have overlapping ${ }^{87} \mathrm{Sr} /{ }^{86} \mathrm{Sr}$ values, as is the case with two of our groupings within the UCR $\mathrm{Su} / \mathrm{F}$ population. With continued research and the emergence of new technologies, the promise of understanding salmon ecology at broad and fine geographic scales will be realized.

Acknowledgements We thank Melinda Davis, Paul Hoffarth, Andrew Murdoch, and Bill Sharp for providing samples; David Kuligowski for collecting genetic data; George Whitman for his technical assistance; anonymous reviewers for improving the paper; and the organizers for the $4^{\text {th }}$ International Otolith Symposium.

Open Access This article is distributed under the terms of the Creative Commons Attribution Noncommercial License which permits any noncommercial use, distribution, and reproduction in any medium, provided the original author(s) and source are credited.

\section{References}

Abaunza P, Murta AG, Campbell N, Cimmaruta R, Comesana AS, Dahle G, Garcia Santamaria MT, Gordo LS, Iversen SA, MacKenzie K, Magoulas A, Mattiucci S, Molloy J, Nascetti G, Pinto AL, Quinta R, Ramos P, Sanjuan A, Santos AT, Stransky C, Zimmermann C (2008) Stock identity of horse mackerel (Trachurus trachurus) in the Northeast Atlantic and Mediterranean Sea: Integrating the results from different stock identification approaches. Fish Res 89:196-209 
Bacon CR, Weber PK, Larson KA, Reisenbichler R, Fitzpatrick JA, Wooden JL (2004) Migration and rearing histories of Chinook salmon (Oncorhynchus tshawytscha) determined by ion microprobe $\mathrm{Sr}$ isotope and $\mathrm{Sr}: \mathrm{Ca}$ transects of otoliths. Can J Fish Aquat Sci 61:2425-2439

Bailey RE, Margolis L (1987) Comparison of the parasite fauna of juvenile sockeye salmon (Oncorhynchus nerka) from southern British Columbia and Washington State lakes. Can J Zool 65:420-431

Barnett-Johnson R (2007) Spatial scales of mixing and natal source contributions of salmon populations in the coastal ocean detected by otolith and genetic signatures of origin. University of California, Dissertation

Barnett-Johnson R, Ramos FC, Grimes CB, MacFarlane RB (2005) Validation of Sr isotopes in otoliths by laser ablation multicollector inductively coupled plasma mass spectrometry (LA-MC-ICPMS): opening avenues in fisheries science applications. Can J Fish Aquat Sci 62:2425-2430

Barnett-Johnson R, Pearson TE, Ramos FC, Grimes CB, MacFarlane RB (2008) Tracking natal origins of salmon using isotopes, otoliths, and landscape geology. Limnol Oceanogr 53:1633-1642

Beacham TD, Candy JR, Jonsen KL, Supernault J, Wetklo M, Deng L, Miller KM, Withler RE, Varnavskaya N (2006) Estimation of stock composition and individual identification of Chinook salmon across the Pacific Rim using microsatellite variation. Trans Am Fish Soc 135:861-888

Botsford LW, Brumbaugh DR, Grimes C, Kellner JB, Largier J, O'Farrell MR, Ralston S, Soulanille E, Wespestad V (2009) Connectivity, sustainability, and yield: bridging the gap between conventional fisheries management and marine protected areas. Rev Fish Biol Fish 19:69-95

Bradbury IR, Campana SE, Bentzen P (2008) Estimating contemporary early life-history dispersal in an estuarine fish: integrating molecular and otolith elemental approaches. Mol Ecol 17:1438-1450

Cadrin SX, Friedland KD, Waldman JR (2005) Stock identification methods: applications in fisheries science. Elsevier Academic Press, San Francisco

Camp VE, Ross ME, Hanson WE (2004) Genesis of flood basalts and Basin and Rang volcanic rocks from the Stenns Mountain to the Malheur River Gorge, Oregon. Geol Soc Am Bull 115:105-128

Campana SE, Thorrold SR (2001) Otoliths, increments, and elements: keys to a comprehensive understanding of fish populations? Can J Fish Aquat Sci 58:30-38

Carlson SM, Seamons TR (2008) A review of quantitative genetic components of fitness in salmonids: implications for adaptation to future change. Evol Appl 1:222-238

Carlson SM, Quinn TP (2007) Ten years of varying lake level and selection in size-at-maturity in sockeye salmon. Ecology 88:2620-2629

Carlson SM, Rich HB, Quinn TP (2009) Does variation in selection imposed by bears drive divergence among populations in the size and shape of sockeye salmon? Evolution 63:1244-1261

Chapman DW (1986) Salmon and steelhead abundance in the Columbia River in the nineteenth century. Trans Am Fish Soc 115:662-670

Cowen RK, Sponaugle S (2009) Larval dispersal and marine population connectivity. Annu Rev Mar Sci 1:443-66
Feyrer F, Hobbs J, Baerwald M, Sommer T, Yin Q, Clark K, May B, Bennett W (2007) Otolith microchemistry provides information complementary to microsatellite DNA for a migratory fish. Trans Am Fish Soc 136:469-476

Fukuhara FM, Murai S, LaLanne JJ, Sribhibhadh A (1962) Continental origin of red salmon as determined from morphological characters. Int North Pacific Fish Comm Bull 8:15-109

Gillanders BM (2002) Temporal and spatial variability in elemental composition of otoliths: implications for determining stock identity and connectivity of populations. Can J Fish Aquat Sci 59:669-679

Henry K (1961) Radical identification of Fraser River sockeye salmon (Oncorhynchus nerka) by means of scales and its application to salmon management. Int North Pacific Fish Comm Bull 12

Hansen MM, Kenchington E, Nielsen EE (2001) Assigning individual fish to populations using microsatellite DNA markers. Fish Fish 2:93-112

Harrington RR, Kennedy BP, Chamberlain CP, Blum JD, Folt $\mathrm{CL}$ (1998) ${ }^{15} \mathrm{~N}$ enrichment in agricultural catchments: field patterns and applications to tracking Atlantic salmon (Salmo salar). Chem Geol 147:281-294

Hauser L, Seamons R, Dauer M, Naish KA, Quinn TP (2006) An empirical verification of population assignment methods by marking and parentage data: hatchery and wild steelhead. Mol Ecol 15:3157

Hobbs JA, Yin Q, Burton J, Bennett WA (2005) Retrospective determination of natal habitats for an estuarine fish with otolith strontium isotope ratios. Mar Freshwat Res 56:655-660

Hobson K, Barnett-Johnson R, Cerling T (2009) Using isoscapes to track animal migration. In: West $\mathrm{J}$, Bowen G, Dawson T, Tu K (eds.) Isoscapes: Understanding movement patterns and processes on earth through isotope mapping. Springer Press, Berlin, Germany, pp 273-298

Hooper PR (1997) The Columbia River flood basalt province: Current status. In: Mahoney JJ, Coffin MF (eds.) Large igneous provinces: Continental, oceanic, and planetary flood volcanism: Am Geophys Union Geophys Monogr 100:1-27

Ingram BL, Weber PK (1999) Salmon origin in California's Sacramento-San Joaquin river system as determined by otolith strontium isotopic composition. Geology 27:851-854

Kalinowski ST, Manlove KR, Taper ML (2007) ONCOR A computer program for genetic stock identification. Department of Ecology, Montana State University, Bozeman, MT. Available at http://www.montana.edu/kalinowski/ kalinowski_software.htm

Kennedy BP, Folt CL, Blum JD, Chamberlain CP (1997) Natural isotope markers in salmon. Nature 387:766-767

Lasmanis R (1991) Geology Wash Rocks Miner 66:262-277

MacKenzie K (2009) The use and abuse of parasites as stock markers for fish. Fish Res 97:1-2

MacCrimmon HR, Claytor RR (1985) Meristic and morphometric identify of Baltic stocks of Atlantic salmon (Salmo salar). Can J Zool 63:2032-2037

Margolis L (1963) Parasites as indicators of the geographic origin of sockeye salmon, Oncorhynchus nerka (Walbaum) occurring in the North Pacific Ocean and adjacent seas. Int North Pacific Fish Comm Bull 11:101-156 
Marques JF, Teixeria CM, Cabral HN (2006) Differentiation of commercially important flatfish populations along the Portuguese coast: Evidence from morphology and parasitology. Fish Res 81:293-305

Marshall S, Bernard D, Conrad R, Cross B, McBride D, McGregor A, McPherson S, Oliver G, Sharr S, Ban Allen B (1987) Application of scale pattern analysis to the management of Alaska's sockeye salmon (Oncorhynchus nerka) fisheries. In: Smith HD, Margolis L, Wood CC (ed) Sockeye salmon (Oncorhynchus nerka) population biology and future management. Can Spec Publ Fish Aquat Sci 96:307-326

Miller JA (2007) Scales of variation in otolith elemental chemistry of juvenile staghorn sculpin (Leptocottus armatus) in three Pacific Northwest estuaries. Mar Biol 151:483-494

Miller JA, Kent AJR (2009) The determination of maternal run time in juvenile Chinook salmon (Oncorhynchus tshawytscha) based on $\mathrm{Sr} / \mathrm{Ca}$ and ${ }^{87} \mathrm{Sr} /{ }^{86} \mathrm{Sr}$ within otolith cores. Fish Res 95:373-378

Miller JA, Banks MA, Gomez-Uchida D, Shanks AL (2005) A comparison of population structure in black rockfish (Sebastes melanops) as determined with otolith microchemistry and microsatellite DNA. Can J Fish Aquat Sci 62:2189-2198

Milton DA, Chenery SP (2001) Can otolith chemistry detect the population structure of the shad hilsa Tenualosa ilisha? Comparison with the results of genetic and morphometric studies. Mar Ecol Prog Ser 222:239-251

Moran P, Teel DJ, LaHood ES, Drake J, Kalinowski S (2006) Standardizing multi-laboratory microsatellite data in $\mathrm{Pa}-$ cific salmon: an historical view of the future. Ecol Freshw Fish 15:597-605

Myers JM, Kope RG, Bryant GJ, Teel D, Lierheimer LJ, Wainwright TC, Grant WS, Waknitz FW, Neely K, Lindley ST, Waples RS (1998) Status review of Chinook salmon from Washington, Idaho, Oregon, and California. U.S. Dept. Commer., NOAA Tech. Memo. NMFSNWFSC-35, 443 p.

Narum SR, Banks M, Beacham TD, Bellinger MR, Campbell MR, Dekoning SJ, Eliz A, Guthrie CM III, Kozfkay C, Miller KM, Moran P, Phillips R, Seeb LW, Smith CT, Warheit K, Young SF, Garza JC (2008) Differentiating salmon populations at broad and fine geographic scales with microsatellite and single nucleotide polymorphisms. Mol Ecol 17:3464-3477

O' Connell M, Wright JM (1997) Microsatellite DNA in fishes. Rev Fish Biol Fisher 7:331-363

Palumbi SR (2004) Marine reserves and ocean neighborhoods: the spatial scale of marine populations and their management. Annu Rev Env Resour 29:31-68

Planes S, Jones GP, Thorrold SR (2009) Larval dispersal connects fish populations in a network of marine protected areas. P Natl Acad Sci USA 106:5693-5697

Ramos FC, Wolff JA, Tollstrup DL (2004) Measuring ${ }^{87} \mathrm{Sr} /{ }^{86} \mathrm{Sr}$ variations in minerals and groundmass from basalts using LA-MC-ICPMS. Chem Geol 211:135-158

Ramos FC, Wolff JA, Tollstrup DL (2006) Sr isotope disequilibrium in Columbia River flood basalts: Evidence for rapid shallow-level open-system processes. Geology $33: 457-460$
Rannala B, Mountain JL (1997) Detecting immigration by using multilocus genotypes. P Natl Acad Sci USA 94:9197-9201

Ruttenberg BI, Warner RR (2006) Spatial variation in the chemical composition of natal otoliths from a reef fish in the Galapagos Islands. Mar Ecol Prog Ser 328:225-236

Seeb LW, Antonovich A, Banks MA, Beacham TD, Bellinger MR, Blankenship SM, Campbell MR, Decovich NA, Garza JC, Guthrie CM III, Lundrigan TA, Moran P, Narum SR, Stephenson JJ, Supernault KJ, Teel DJ, Templin WD, Wenburg JK, Young SF, Smith CT (2007) Development of a standardized DNA database for Chinook Salmon. Fisheries 32:540-552

Secor DH (1999) Specifying divergent migrations in the concept of stock: the contingent hypothesis. Fish Res 43:13-34

Selkoe KA, Henzler CM, Gaines SD (2008) Seascape genetics and the spatial ecology of marine populations. Fish Fish 9:363-377

Singleton MJ, Maher K, DePaulo DJ, Conrad ME, Dresel PE (2006) Dissolution rates and vadose zone drainage from strontium isotope measurements of groundwater in Pasco Basin, WA unconfined aquifer. J Hydrol 321:39-58

Standish JD, Sheehy M, Warner RR (2008) Use of otolith natal elemental signatures as natural tags to evaluate connectivity among open-coast fish populations. Mar Ecol Prog Ser 356:259-268

Taylor EB (1991) A review of local adaptation in salmonidae, with particular reference to Pacific and Atlantic salmon. Aquaculture 98:185-207

Thresher RE (1999) Elemental composition of otoliths as a stock delineator in fishes. Fish Res 43:165-204

Utter F, Teel D, Milner G, McIsaac D (1987) Genetic estimates of stock compositions of 1983 Chinook salmon harvests off the Washington Coast and the Columbia River. Fish Bull 85:13-23

Utter FM, Chapman DW, Marshall AR (1995) Genetic population structure and history of Chinook salmon of the Upper Columbia River. Am Fish Soc Symp 17:149165

Waknitz, FW, Mathews GM, Wainwright T, Winans GA (1995) Status review for Mid-Columbia River summer Chinook salmon. NOAA Tech. Mem. NMFS-NWFSC-22, 80 p. (Available from Natl. Mar. Fish. Serv., Northwest Fisheries Science Center, Coastal Zone and Estuarine Studies Division, 2725 Montlake Blvd. E., Seattle, WA 981122097)

Walther BD, Thorrold SR (2008) Geochemical signatures in otoliths record natal origins in American shad. Trans Amer Fish Soc 137:57-69

Waples RS, Gustafson RG, Weitkamp LA, Myers JM, Johnson OW, Busby PJ, Hard JJ, Bryant GJ, Waknitz FW, Neely K, Teel D, Grant WS, Winans GA, Phelps S, Marshall A, Baker B (2001) Characterizing diversity in salmon from the Pacific Northwest Journal of Fish Biology 59 (Suppl. A): $1-41$

Waples RS, Teel DJ, Myers JM, Marshall AM (2004) Life history variation in Chinook salmon: historic contingency and parallel evolution. Evolution 58:386-403

Weitkamp LA (2010) Marine distributions of Chinook salmon (Oncorhynchus tshawytscha) from the West Coast of 
North America determined by coded wire tag recoveries. Trans Am Fish Soc 139:147-170

Weissenborn AE (1969) Geologic map of Washington: U.S. Geological Survey, Miscellaneous Geologic Investigations Map I-583, scale 1:2000000

Winans GA (1984) Multivariate morphometric variability in Pacific salmon: technical demonstration. Can J Fish Aquat Sci 41:1150-1159
Winans GA, Viele D, Grover A, Palmer-Zwahlen M, Teel D, Van Doornik D (2001) Update of genetic stock identification of Chinook salmon in the Pacific Northwest: Test fisheries in California. Rev Fish Sci 9:213-237

Wood CC, Rutherford DT, McKinnell S (1989) Identification of sockeye salmon (Oncorhynchus nerka) stocks in mixed-stock fisheries in British Columbia and southeast Alaska using biological markers. Can J Fish Aquat Sci 46:2108-2120 